\title{
Aktivitas Biologis Asap Cair Batang Manggis (Garcinia mangostana L.) Terhadap Viabilitas Streptococcussp. (L.10.3)
}

\author{
Lilis Susanti ${ }^{1}$, Elvi Rusmiyanto P. ${ }^{\mathbf{1}}$, Rikhsan Kurniatuhadi ${ }^{1}$ \\ Program Studi Biologi, Fakultas MIPA, Universitas Tanjungpura, Jl. Prof. Dr. H. Hadari Nawawi,Pontianak, \\ Email korespondensi: lilissusanty123@gmail.com
}

\begin{abstract}
The wood vinegar of the stem of mangosteen (G. mangostana L.) is the result of pyrolysis of the stem which is condensed into steam. Wood vinegar contains acid and phenol compounds that have antibacterial activities. This research aims to determine the biological activities of the wood vinegar of the stem of mangosteen $(G$. mangostana L.) on the viability of Streptococcus sp. (L.10.3) and determine the concentration of wood vinegar of the stem of mangosteen (G. mangostana L.) which is effective in inhibiting the growth of Streptococcus sp. (L.10.3). This research used a completely randomized design (CRD) with 6 treatments consisting of wood vinegar with a concentration of $0.1(\mathrm{Tl}) ; 0.5$ (T2); 1 (T3) and 1.5\% (T4), negative controls namely sterile distilled water (T5), and positive control namely chlorhexidine of $0.2 \%$ (T6). The viability test used the dilution method and calculation of the number of colonies using the total plate count (TPC) method, each treatment was repeated four times. The results showed the increasing concentration of wood vinegar of the stem of mangosteen (G. mangostana L.) and the decreasing amount of Streptococcus sp. (L.IO.3). Wood vinegar at concentration $1.5 \%$ showed bacterial growth of $6.9 \times 10^{5} \mathrm{CFU} / \mathrm{ml}$ which was very different from sterile distilled water by $2.5 \times 107 \mathrm{CFU} / \mathrm{ml}$ with inhibition up to $96.9 \%$ and not significantly different from chlorhexidine of $0.2 \%$.
\end{abstract}

Keywords : Garcinia mangostana, Inhibition, Wood vinegar, Streptococcus sp., Viability.

\section{PENDAHULUAN}

Permasalahan gigi dan mulut yang dialami oleh sebagian besar masyarakat Indonesia adalah karies gigi (Wardani, 2012). Hasil survey kesehatan rumah tangga oleh Depertemen Kesehatan RI tahun 2004 menyatakan bahwa prevalensi karies gigi penduduk Indonesia mencapai 90,05\%. Sedangkan menurut Depertemen Kesehatan RI tahun 2012 prevalensi karies gigi terbesar terjadi pada anak usia 12 tahun yaitu $43,4 \%$. Proses pembentukan karies diketahui akibat adanya aktivitas golongan bakteri oral Streptococci (Wardani, 2012).

Golongan bakteri Streptococcus sebagian besar merupakan bakteri gram positif yang berperan dalam pembentukan plak gigi. Beberapa bakteri golongan Streptococcus dapat memfermentasi karbohidrat menjadi glukan dari sisa makanan yang melekat di gigi. Plak gigi menjadi media pertumbuhan bakteri golongan Streptococcus. Selain menghasilkan glukan, bakteri golongan Oral Streptococci seperti $S$. mutans dapat memfermentasi gula menjadi asam. Asam yang dihasilkan secara terus menerus mengakibatkan demineralisasi permukaan email gigi sehingga terjadi karies gigi (Nahak, 2013). Karies gigi dapat dicegah dengan mengontrol pertumbuhan bakteri penyebab plak dengan senyawa antibakteri pada tumbuhan (Newman, 2006).
Menurut Judoamidjojo et al., (1989) tumbuhan manggis (Garcinia mangostana L.) terutama pada bagian batang mengandung senyawa lignin, sukrosa dan hemiselulosa. Senyawa-senyawa tersebut dapat didegredasi menjadi beberapa senyawa fenol dan senyawa asam dari proses pritolisis yang memiliki aktivitas antibakteri, karena menurut penelitian Yefrida et al., (2009) senyawa asam dan fenol pada asap cair dapat menghambat pertumbuhan bakteri gram positif pada konsentrasi $10 \%$.

Batang manggis dalam masyarakat dimanfaatkan oleh pengrajin mebel untuk pembuatan kusen. Proses pembuatan kusen tersebut menghasilkan limbah yang dapat dimanfaatkan kembali sebagai bahan untuk pembuatan asap cair. Penelitian sebelumnya yang dilakukan oleh Ginayati et al., 2015, memanfaatkan asap cair cangkang kelapa sawit sebagai pengawet tahu dengan konsentrasi $0,5 \%$. Kemampuan asap cair sebagai pengawet bahan makanan karena asap cair dapat menghambat pertumbuhan bakteri sehingga memperlambat pembusukan (Ginayati et al.,2015). Berdasarkan hal tersebut perlu dilakukan penelitian mengenai aktivitas biologis asap cair batang manggis ( $G$. mangostana L.) terhadap viabilitas Streptococcus sp.(L.10.3). 


\section{BAHAN DAN METODE} Waktu dan Tempat Penelitian

Penelitian ini dilakukan pada bulan Januari hingga Maret 2018. Isolasi bakteri serta uji aktivitas biologis asap cair batang manggis ( $G$. mangostana L.) terhadap viabilitas Streptococcus sp. (L.10.3) dilakukan di Laboratorium Mikrobiologi Jurusan Biologi, Fakultas Matematika dan Ilmu Pengetahuan Alam, Universitas Tanjungpura Pontianak.

\section{Bahan}

Bahan yang digunakan dalam penelitian yaitu asap cair batang manggis ( $G$ mangostana $\mathrm{L}$.) koleksi di Laboratorium Mikrobiologi Fakultas MIPA Universitas Tanjungpura Pontianak, aquades, alpha napthol, agar, chlorhexidine 0,2\%, etanol $95 \%$, indikator phenol red, iodium, isolat Streptococcus sp. (L.10.3), $\mathrm{KOH} 40 \%$, krystal viole, larutan standard Mcfarland 0,5\%, larutan $\mathrm{H}_{2} \mathrm{O}_{2} 3 \%$. Media Nutrient Agar (NA), Nutrient Broth (NB), pepton dan medium uji biokimia yaitu media gula-gula manitol, sorbitol, Motility Indole Ornithine Agar (MIO), Triple Sugar Iron Agar (TSIA) dan MR-VP (methyl red dan voges proskauer) dan safranin.

\section{Rancangan Penelitian}

Penelitian ini merupakan penelitian real eksperiment menggunakan rancangan acak lengkap (RAL) dengan enam taraf perlakuan dan empat kali ulangan yaitu: $\mathrm{T} 1$ Konsentrasi asap cair $0,1 \%$, T2 $0,5 \%$, T3 1\%, T4 1,5\%, T5 Aquades steril. T6 Konsentrasi clorhexidine 0,2\%.

\section{Prosedur Kerja}

Preparasi alat dan bahan

Alat-alat yang terbuat dari kaca dicuci bersih menggunakan detergen dan dikeringkan kemudian disterilisasi menggunakan autoklaf selama 20 menit pada suhu $121^{\circ} \mathrm{C}$.

Media Nutrient Agar (NA) dan Nutrient Broth (NB) dibuat sebanyak 1 liter. Media pengujian biokimia seperti Motility Indole Ornithine (MIO), Triple Sugar Iron Agar (TSIA), dan MR-VP (methyl red dan voges proskauer), Manitol dan Sorbitol masingmasing dibuat sebanyak $100 \mathrm{ml}$. Selanjutnya media disterilisasi dengan autoklaf selama 15 menit pada suhu $121^{\circ} \mathrm{C}$.

\section{Pengenceran Asap Cair}

Asap cair $100 \%$ diencarkan menjadi 10\% menggunakan akuades steril. Pengenceran setiap konsentrasi dibuat sebanyak $5 \mathrm{ml}$, konsentrasi $1,5 \%$ dibuat dengan cara melarutkan $0,75 \mathrm{ml}$ asap cair $10 \%$ ke dalam 4,25 ml akuades. Konsentrasi $1 \%$ dibuat dengan melarutkan $0,5 \mathrm{ml}$ asap cair $10 \%$ ke dalam 4,5 ml akuades, dan konsentrasi 0,5\% dibuat dengan melarutkan $0,25 \mathrm{ml}$ asap cair $10 \%$ kedalam $4,75 \mathrm{ml}$ akuades steril serta konsentrasi $0,1 \%$ dibuat dengan melarutkan $0,05 \mathrm{ml}$ asap cair $10 \%$ ke dalam $4,95 \mathrm{ml}$ akuades steril.

\section{Pengambilan Sampel Bakteri}

Bakteri Streptococcus sp.(L.10.3) diisolasi dari plak gigi dengan cara mengoleskan cotton bud steril pada gigi. Sampel kemudian dikultur dengan cara diapus pada media Nutrien Agar (NA) dan diinkubasi pada suhu $37^{\circ} \mathrm{C}$ selama 24 jam.

\section{Identifikasi Bakteri}

Identifikasi bakteri dilakukan dengan mengamati bentuk, elevasi, dan tepian koloni, dilanjutkan dengan mengamati bentuk, formasi, dan gram dari sel bakteri, kemudian dilakukan uji fisiologis (Uji motilitas) dan uji biokimia (Uji voges poskauer, citrat, manitol, sorbitol, glukosa, sukrosa, laktosa, pembentukan gas $\mathrm{H}_{2} \mathrm{~S}, \mathrm{CO}_{2}$ dan katalase) kemudian karakter-karakter bakteri tersebut dibandingkan dengan Streptococcus berdasarkan buku Bergey's Manual Of Determinative Bacteriology oleh Holt et al.,(1995) dan Manual for the Identification Of Medical Bacteria (Second Edition) oleh Cowan and Steel`s (1974).

\section{Uji Pewarnaan Gram}

Uji pewarnaan gram dilakukan dengan mengapus Isolat bakteri di atas kaca objek, dan ditetesi kristal violet selama 1 menit kemudian dibilas dengan akuades steril. Kaca objek dikeringanginkan dan ditetesi larutan iodin selama satu menit kemudian bilas dengan akuades teril. Perlakuan dilanjutkan dengan menetesi etanol $95 \%$ selama 30 detik dan dibilas dengan akuades steril. Selanjutnya ditetesi safranin selama 30 detik dan dibilas dengan akuades kemudian kaca objek dikeringkan. Preparat diamati di bawah mikroskop dengan melihat warna, bentuk bakteri dan formasi sel bakteri. Bakteri yang menunjukkan warna merahmerupakan gram negatif dan warna ungu merupakan gram positif (Waluyo, 2008).

\section{Uji Motilitas}

Uji motilitas dilakukan untuk mengetahui adanya pergerakan (motilitas) bakteri. Isolat bakteri diambil menggnakan ose lurus yang ditusukan secara vertikal pada media Motility Indole Ornithine Agar (MIO) dan diinkubasi selama 24 jam. Hasil positif ditandai dengan adanya penyebaran koloni bakteri dari garis tusukan (Budiarso, 2014). 


\section{Uji Biokimia}

Uji Fermentasi Karbohidrat, Pembentukan $\mathrm{CO}_{2}$ dan $\mathrm{H}_{2} \mathrm{~S}$

Uji fermentasi karbohidrat dilakukan dengan menggunakan media Triple Sugar Iron Agar (TSIA) dengan cara menusukkan inokulum bakteri secara vertikal sedalam 3/4 pada media miring dan digores pada bagian slant media kemudian diinkubasi selama 24 jam. Hasil positif bakteri memfermentasi glukosa ditandai dengan bagian dasar (butt) media akan berwarna kuning bagian slant tetap berwarna merah, sedangkan jika mikroorganisme memfermentasi laktosa dan sukrosa ditandai dengan bagian slant dan butt media berubah berwarna kuning. Media TSIA juga dapat digunakan untuk pengujian produksi gas $\mathrm{H}_{2}, \mathrm{~S}$ dan $\mathrm{CO}_{2}$ oleh bakteri. Hasil positif $\mathrm{H}_{2}, \mathrm{~S}$ ditandai dengan adanya endapan hitam pada dasar media dan Uji $\mathrm{CO}_{2}$ positif ditandai dengan terangkatnya media (Hold et al., 1995).

\section{Uji VP(Voges Proskauer)}

Uji VP (Voges Proskauer) dilakukan untuk mengetahui adanya fermentasi asam campuran (butanadiol). Uji ini dilakukan dengan cara mengambil satu ose isolat bakteri kemudian diinokulasikan ke dalam media MR-VP (methyl red dan voges proskauer) dan diinkubasi pada suhu $28^{\circ} \mathrm{C}$ selama 24 jam. Media ditetesi oe-naphtol dan ditambah $1 / 4$ tabung KOH $40 \%$ kemudian media dikocok selama 15 menit, hasil positif ditandai dengan perubahan warna media menjadi merah muda (Hold et al., 1995).

\section{Uji Fermentasi Manitol dan Sorbitol}

Uji dilakukan dengan cara menginokulasikan isolat bakteri menggunakan ose steril kemudian dicelupkan pada media manitol dan sorbitol pada tabung reaksi kemudian diinkubasi selama 24 jam. Hasil positif ditandai dengan terjadinya perubahan warna media menjadi kuning (Hold et al., 1995).

\section{Uji Katalase}

Uji katalase dilakukan dengan meneteskan hidrogen peroksida $\left(\mathrm{H}_{2} \mathrm{O}_{2}\right) 3 \%$ pada glass objek steril. Biakan bakteri dioleskan pada glass objek yang sudah ditetesi hidrogen peroksida $\left(\mathrm{H}_{2} \mathrm{O}_{2}\right)$. Hasil posif ditandai dengan terbentuknya gelembung udara (Budiarso, 2014).

\section{Pembuatan Suspensi Bakteri}

Isolat Streptococcus sp. (L.10.3) yang berumur 24 jam dimasukkan ke dalam larutan $\mathrm{NaCl}$ 0,95\% sebanyak $9 \mathrm{ml}$ di dalam cawan petri sampai kekeruhannya setara dengan standar McFarland 0,5. Standar McFarland 0,5 setara dengan 1,5 X $10^{8}$ $\mathrm{CFU} / \mathrm{ml}$ jumlah bakteri. Larutan ini dibuat dengan mencampurkan $0,5 \mathrm{ml}$ larutan $1,175 \% \mathrm{BaCl}_{2}$ dan 9,95 ml larutan $1 \% \mathrm{H}_{2} \mathrm{SO}_{4}$ di dalam tabung reaksi (Soelama et al., 2015).

\section{Uji Viabilitas}

Uji viabilitas dilalukan dengan menyiapkan tabung reaksi $\mathrm{T} 1, \mathrm{~T} 2, \mathrm{~T} 3, \mathrm{~T} 4, \mathrm{~T} 5$ dan T6. Tabung T1 dimasukan $1 \mathrm{ml}$ asap cair dengan konsentrasi 0,1\% dan tabung T2 diisi $1 \mathrm{ml}$ asap cair 0,5\%. Tabung T3 dimasukan $1 \mathrm{ml}$ asap cair dengan konsentrasi $1 \%$ dan T4 dimasukan $1 \mathrm{ml}$ asap cair dengan konsentrasi 1,5\%. Tabung T5 dimasukan $1 \mathrm{ml}$ akuades steril dan T6 dimasukan $1 \mathrm{ml}$ clorhexidine 0,2\%. Masing-masing tabung T1, T2, T3, T4, T5, T6 dimasukan $5 \mathrm{ml}$ media NB dan $1 \mathrm{ml}$ suspensi bakteri kemudian diinkubasi selama 24 jam.

Sampel uji (T1 sampai T6) selanjutnya dilakukan perhitungan jumlah koloni dengan metode total plate count (TPC) dengan pengenceran lima seri yaitu $10^{-1}, \mathrm{~T}_{1} 10^{-2}, 10^{3}, 10^{4}$ dan $10^{5}$, masing-masing tabunng diisi $5 \mathrm{ml}$ garam fisiologis. tabung T1 yang sudah diinkubasi diambil sebayak $1 \mathrm{ml}$ di masukan ke tabung $\mathrm{T}_{1} 10^{-1}$ kemudian divortex, selanjutnya dari tabung $\mathrm{T}_{1} 10^{-1}$ diambil $1 \mathrm{ml}$ dan dimasukan ke tabung $\mathrm{T}_{1} 10^{-2}$, perlakuan dilanjutkan dengan cara yang sama sampai tabung ke- $\mathrm{T}_{1} 10^{-4}$ dan tabung $\mathrm{T}_{1} 10^{-5}$. Pengenceran pampel uji T2, T3, T4, T5 dan T6 dilakukan cara yang sama dengan perlakuan T1.

Pengujian dilanjutkan dengan menanam $1 \mathrm{ml}$ sampel uji pada media NA $20 \mathrm{ml}$ pada pengenceran ke $10^{-3}, 10^{-4}, 10^{-5}$ dari masing-masing tabung uji $\mathrm{T} 1$, T2, T3, T4, T5 dan T6. Masing-masing perlakuan diinkubasi pada suhu $37^{\circ} \mathrm{C}$ selama 24 jam dan dilakukan perhitung jumlah bakteri (Soelama et al., 2015).

\section{Perhitungan Jumlah Bakteri}

Jumlah koloni bakteri yang tumbuh setelah perlakuan dihitung menggunkan metode hitung cawan petri total plate count (TPC), yaitu penghitungan secara tidak langsung dan hanya mengetahui jumlah bakteri yang hidup (viable count). Metode ini memiliki standard perhitungan yaitu standard plate count (SPC). SPC merupakan teknik perhitungan bakteri dengan range 30-300 CFU (colony forming unit)/ml dari pengenceran 10 ${ }^{3}, 10^{-4}, 10^{-5}$ (Yunita et al., 2015).

\section{Analisis Data}

Data dianalisis dengan ANOVA satu jalur menggunakan program SPSS 18. Jika terdapat pengaruh asap cair batang manggis (G. mangostana L.) terhadap viabilitas Streptococcus sp.(L.10.3), dilakukan uji lanjut menggunakan uji Tukey untuk melihat konsentrasi efektif dalam menghambat 
pertumbuhan Streptococcus sp. (L.10.3) pada taraf kepercayaan $95 \%$.

\section{HASIL DAN PEMBAHASAN}

\section{Hasil}

Hasil Karakterisasi dan Identifikasi Streptococcus sp. (L.10.3)

Isolasi bakteri plak gigi yang diinkubasi selama 24 jam pada media NA (Nutrient Agar) menunjukkan beberapa karakter morfologis Streptococcus yang dapat dilihat pada Gambar 1.
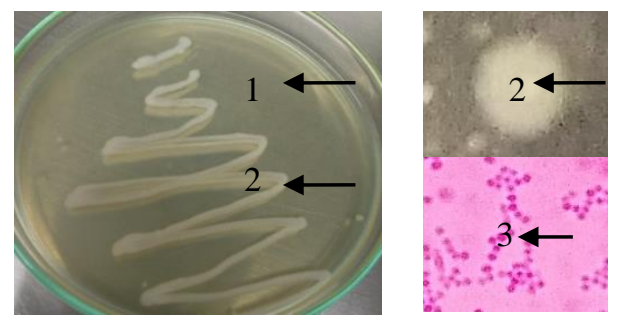

Gambar 1 Morfologi bakteri Streptococcus sp. (L.10.3); 1.Media Nutrient Agar, 2. Koloni Streptococcus sp. (L.10.3) 3. $\quad$ Sel Streptococcus sp.(L.10.3) (perbesaran 1000×)

Analisis karakter morfologis koloni bakteri (L.10.3) berbentuk bulat, tepian rata, elevasi cembung, berwarna putih susu dan transparan. Karakter morfologis sel menunjukkan bakteri berbentuk Coccus (bulat), gram positif dengan formasi rantai. Identifikasi dilanjutkan dengan uji biokimia yang dapat dilihat pada Tabel 1 .

Tabel 1 Hasil Uji Biokimia Bakteri L.10.3

\begin{tabular}{ccc}
\hline No & Jenis Uji & reaksi \\
\hline 1. & Voges poskauer & + \\
2. & Manitol & + \\
3. & Sorbitol & + \\
4. & Glukosa & + \\
5. & Sukrosa & + \\
6. & Laktosa & + \\
7. & $\mathrm{CO}_{2}$ & - \\
8. & $\mathrm{H}_{2} \mathrm{~S}$ & - \\
9. & Katalase & - \\
10. & Motilitas & -
\end{tabular}

Keterangan: $+=$ Positif dan $-=$ Negatif

Uji biokimia isolat L.10.3 menunjukkan positif memfermentasi karbohidrat, positif uji voges poskauer dan negatif katalase, tidak memproduksi gas $\mathrm{CO}_{2}$ dan $\mathrm{H}_{2} \mathrm{~S}$, serta tidak bergerak (nonmotil).

Hasil Viabilitas Streptococcus sp. (L.10.3)

Viabilitas bakteri diukur dengan menghitung jumlah bakteri menggunakan jumlah koloni yang tumbuh dan berkembang dalam media NA (Nutrient
Agar) menggunakan metode SPC. Viabilitas Streptococcus sp. (L.10.3) terhadap berbedaan konsentrasi asap cair batang manggis dapat dilihat pada Gambar 2.

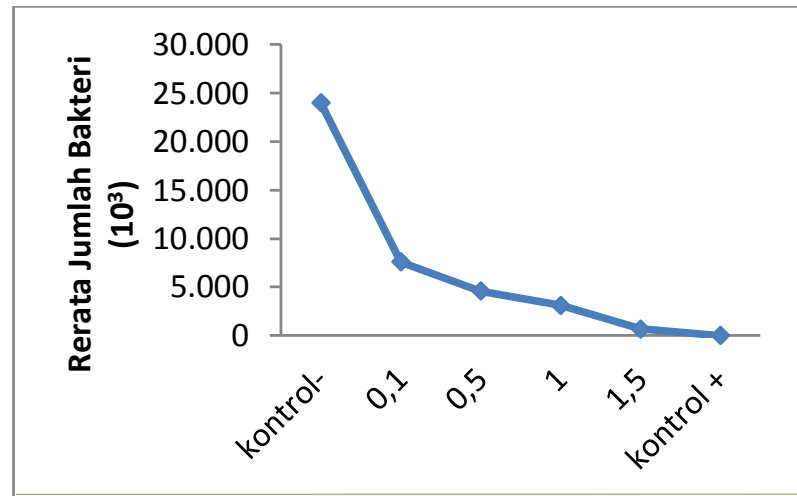

Gambar 2 Grafik Viabilitas Streptococcus sp.(L.10.3) terhadap perbedaan konsentrasi asap cair batang manggis (Garcinia mangostana L.) dalam waktu 24 jam.

Berdasarkan Gambar 2 Viabilitas Streptococcus sp. semakin menurun dengan bertambahnya konsentrasi asap cair batang manggis ( $G$. mangostana L.). Viabilias bakteri dipengaruhi oleh jumlah bakteri yang berbeda akibat aktivitas antibakteri dari asap cair batang manggis. Hasil perhitungan jumlah Streptococcus sp. (L.10.3) dapat dilihat pada Gambar 3.

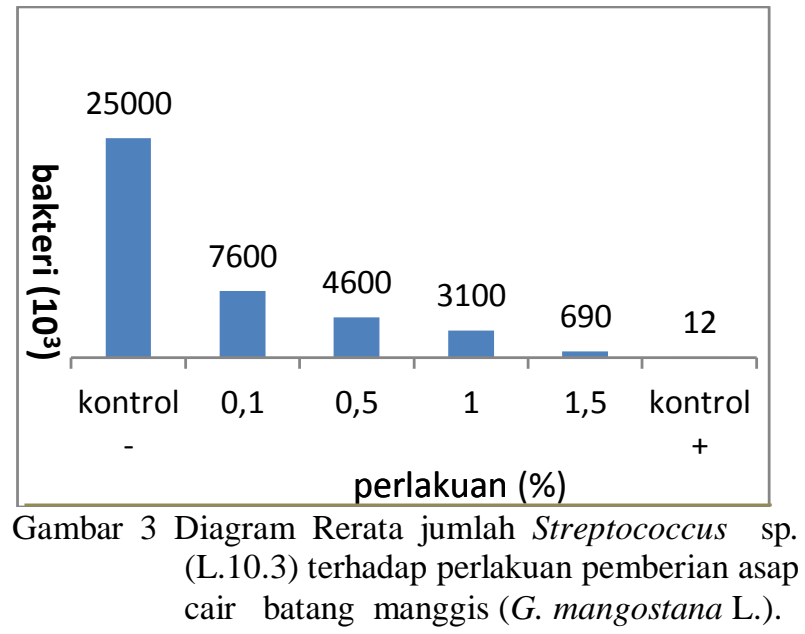

Jumlah Streptococcus sp. (L.10.3) semakin menurun dengan bertambahnya konsentrasi asap cair batang manggis (G. mangostana L.). Masingmassing konsentrasi menunjukkan jumlah yang berbeda dengan kontrol positif dan kontrol negatif. Hasil analisis ANOVA menunjukkan asap cair batang manggis ( $G$. mangostana L.) berpengaruh nyata terhadap viabilitas Streptococcus sp. (L.10.3) $\left(\mathrm{F}_{5,23}=821,321, P=0,00\right.$ ANOVA $)$ yang dapat dilihat pada Tabel 2. 
Tabel 2. Viabilitas Streptococcus sp. (L.10.3) Terhadap Perlakuan Pemberian Asap Cair Batang Manggis (Garcinia mangostana L.)

\begin{tabular}{ccc}
\hline No & Perlakuan $(\%)$ & Hasil Analisis \\
\hline 1 & Kontrol - & $7,5 \pm 0,066^{\mathrm{a}}$ \\
2 & 0,1 & $6,9 \pm 0,042^{\mathrm{b}}$ \\
3 & 0,5 & $6,7 \pm 0,033^{\mathrm{c}}$ \\
4 & 1 & $6,5 \pm 0,123^{\mathrm{d}}$ \\
5 & 1,5 & $5,8 \pm 0,120^{\mathrm{e}}$ \\
6 & kontrol + & $4,0 \pm, 057^{\mathrm{f}}$
\end{tabular}

Keterangan; Angka-angka pada kolom yang diikuti huruf yang tidak sama menunjukkan pengaruh berbeda nyata menurut uji Tukey pada signifikasi $5 \%$.

Analisis viabilitas Streptococcus sp. (L.10.3) terhadap perlakuan konsentrasi yang bervariasi pada uji lanjut Tukey menunjukkan hasil yang berbeda nyata pada setiap konsentrasi dan perlakuan kontrol positif yaitu chlorhexidine $0,2 \%$ dan kontrol negatif yaitu akuades steril. Tabel 2 menunjukkan jumlah sel paling kecil ditunjukan pada konsentrasi $1,5 \%$ yang berbeda nyata dengan chlorhexidine $0,2 \%$ dan data jumlah bakteri terendah pada konsentrasi $0,1 \%$ menunjukkan hasil berbeda nyata dengan akuades steril.

Hasil Persentase Penghambatan Asap Cair Batang Manggis (Garcinia mangostana L.) Terhadap Streptococcus sp. (L.10.3).

Persentase penghambatan menunjukkan kemampuan asap cair batang manggis ( $G$. mangostana L.) dalam mengurangi jumlah Streptococcus sp. (L.10.3). Hasil perhitungan persentase penghambatan asap cair batang manggis (G. mangostana L.) dapat dilihat pada Gambar 4.

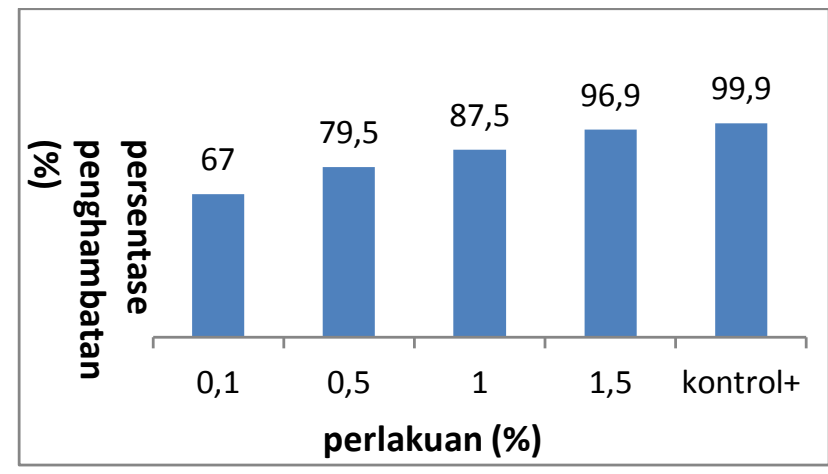

Gambar 4. Diagram Persentase penghambatan asap cair batang manggis ( $G$. manggostana L.) terhadap Streptococcus sp. (L.10.3).

Berdasarkan Gambar 4 persentase penghambatan asap cair berbanding lurus dengan pertambahan konsentrasi asap cair, artinya semakin tinggi konsentrasi asap cair maka persentase penghambatan juga semakin tinggi. Analisis ANOVA dengan uji lanjut Tukey menunjukkan persentase penghambatan asap cair sangat berbeda nyata dari setiap konsentrasi $\left(\mathrm{F}_{4,19}=117,318, P=\right.$ 0,000 ANOVA). Hasil analisis dapat dilihat dalam tabel berikut.

Tabel 3. Perhitungan Persentase Penghambatan Streptococcus sp.(L.10.3) Berdasarkan Perbedaan Konsentrasi Asap Cair Batang Manggis ( $G$. mangostana L.) Selama 24 Jam

\begin{tabular}{ccc}
\hline No & Perlakuan (\%) & Persentase Penghambatan (\%) \\
\hline 1 & 0,1 & $1,82 \pm 0,021^{\mathrm{a}}$ \\
2 & 0,5 & $1,897 \pm 0,016^{\mathrm{b}}$ \\
3 & 1 & $1,939 \pm 0,009^{\mathrm{c}}$ \\
4 & 1,5 & $1,986 \pm 0,006^{\mathrm{d}}$ \\
5 & Kontrol+ & $1,999 \pm 0,00^{\mathrm{d}}$ \\
\hline
\end{tabular}

Keterangan; Angka-angka pada kolom yang diikuti huruf yang tidak sama menunjukkan pengaruh berbeda nyata menurut uji Tukey pada signifikasi $5 \%$.

Hasil analisis menunjukkan bahwa persentase penghambatan berbeda nyata pada setiap konsentrasi dan pada konsentrasi 1,5\% tidak berbeda nyata dengan control + yaitu $1,986 \pm 0,006^{\mathrm{d}}$ dan $1,999 \pm 0,00^{\mathrm{d}}$. Berdasarkan hal ini asap cair batang manggis ( $G$. mangostana L.) pada konsentrasi $1,5 \%$ efektif dalam menghambat Streptococcus sp.(L.10.3).

\section{PEMBAHASAN}

Kelompok bakteri Oral Streptococci merupakan bakteri yang hidup di lingkungan rongga mulut, baik pada plak, saliva maupun gigi. Bakteri golongan tersebut berkaitan dengan pembentukan plak dan karies gigi (Wardani 2012). Isolat bakteri L.10.3 diambil dari plak gigi karena pada plak terdapat berbagai mikroorganisme yang berkembang biak termasuk bakteri golongan Streptococcus (Nahak, 2013).

Berdasarkan hasil inkubasi selama 24 jam, isolat bakteri L.10.3 menunjukkan koloni berbentuk bulat, berwarna putih, tepian rata, serta elevasi cembung dan tembus cahaya (Gambar 1). Berdasarkan buku Bergey's Manual Of Determinative Bacteriology oleh Holt et al., (1995), koloni tersebut diyakini sebagai Streptococcus sp.. Pernyataan ini diperkuat oleh penelitian Heriandi dan Yuke, (2004) yang mengidentifikasi bentuk morfologi koloni bakteri Streptococcus pada plak gigi anak, menyatakan permukaan koloni Streptococcus cembung (konveks) dan transparan (tembus cahaya).

Hasil tersebut juga diperkuat dengan bentuk koloni dan formasi sel bakteri yang menunjukkan hasil berbentuk kokus dengan formasi sel berbentuk rantai (strepto) serta gram positif. Menurut Holt et al., (1995) dan Cowan and Steels, (1974) bakteri 
tersebut merupakan Streptococcus sp.. Hal ini juga didasari oleh hasil uji biokimia dan uji fisiologis yang sudah dilakukan. Hasil tersebut menunjukkan positif uji voges poskauer (VP), uji fermentasi karbohidrat manitol, sorbitol, glukosa, sukrosa, dan laktosa, serta negatif uji pembentukan gas $\mathrm{CO}_{2}$ dan $\mathrm{H}_{2} \mathrm{~S}$, serta negatif uji katalase. Uji fisiologis yang dilakukan yaitu uji motilitas yang menunjukkan bahwa bakteri bersifat nonmotil (tidak bergerak).

Menurut Holt et al., (1995) terdapat empat jenis bakteri Genus Oral Streptococci yang positif uji voges poskauer (VP) yaitu $S$. mutans, $S$. rattus, $S$. salivarius dan sanguis. Uji VP merupakan uji untuk mengidentifikasi bakteri yang dapat memfermentasi karbohidrat menjadi 2,3-Butanadiol, dalam uji penambahan $40 \% \mathrm{KOH}$ dan $5 \%$ larutan $\alpha$-naphtol dapat menetukan adanya asetolin (asetilmethylkarbinol) yaitu senyawa sintetis 2,3butanadiol. Hasil uji fermentasi karbohidrat yaitu manitol, sorbitol, glukosa, sukrosa dan laktosa dan uji motilitas bakteri $S$. mutans, $S$. rattus menunjukkan karakter yang sama dengan hasil pengujian (Tabel 1) (Holt et al., 1995 dan Cowan and Steels, 1974).

Uji fermentasi karbohidrat glukosa, sukrosa, laktosa dilakukan pada media TSIA bersama-sama dengan uji pembentukan $\mathrm{Gas}^{\mathrm{CO}_{2}}$ dan $\mathrm{H}_{2} \mathrm{~S}$. Sedangkan pada uji manitol dan sorbitol dilakukan pada media manitol dan sorbitol yang di buat terpisah. Menurut Holt et al., 1995 dan Cowan and Steels, 1974 bakteri Genus Streptococcus tidak menghasilkan gas dalam proses metabolisme dan tidak menghasilkan enzin katalase serta bersifat nonmotil (tidak bergerak). Menurut Budiarso, (2014) bakteri nonmotil (tidak bergerak) disebabkan karena bakteri tersebut tidak memiliki flagela.

Uji katalase merupakan uji yang dilakukan untuk membedakan Genus Staphylococcus dan Streptococcus. Hasil positif ditunjukan oleh semua Genus Staphylococcus dan semua Genus Streptococcus tidak menghasilkan enzim katalase (Toelle \& Viktor, 2014). Bakteri yang memiliki enzim katalase yang dapat menguraikan $\mathrm{H}_{2} \mathrm{O}_{2}$ menjadi $\mathrm{H}_{2} \mathrm{O}$ dan $\mathrm{O}_{2}$ sehingga hasil positif ditunjukan dengan adanya reaksi bergelembung (Budiarso, 2014).

Berdasarkan uji morfologi koloni (bentuk, elevasi dan tepian), uji morfologi sel (bentuk, formasi, dan gram), uji fisiologis (uji motilitas), isolat L.10.3 menunjukkan karakter bakteri dari golongan Streptococcus. Setelah dilakukan uji biokimia (Uji manitol, sorbitol, glukosa, sukrosa, laktosa, voges poskauer, dan katalase), isolat L.10.3 menunjukkan karakter yang dimiliki oleh S. mutans dan S. rattus (Holt et al., 1995)

Uji viabilitas yang dilakukan pada penelitian ini dilakukan dengan perlakuan konsentrasi 0,$1 ; 0,5 ; 1$; dan $1,5 \%$, serta kontrol negatif yaitu akuades steril dan kontrol positif yaitu chlorhexidine $0,2 \%$. Berdasarkan Grafik pada Gambar 2 menunjukkan pada waktu 24 jam viabilitas bakteri menurun seiring dengan pertambahan jumlah konsentrasi dan konsentrasi $1,5 \%$ menunjukkan viabilitas bakteri paling rendah. Berdasarkan hasil penelitian pada konsentrasi $1,5 \%$ menunjukkan jumlah bakteri sebanyak $6,9 \times 10^{5} \mathrm{CFU} / \mathrm{ml}$. Tingkat viabilitas bakteri berbanding terbalik dengan pertambahan jumlah konsentrasi asap cair, semakin besar konsentrasi asap cair batang manggis ( $G$. mangostana L) maka tingkat viabilitas bakteri semakin kecil. Hal ini terjadi karena semakin besar konsentrasi asap cair maka semakin besar kandungan senyawa fenol, sehingga mempengaruhi tingkat pertumbuhan dan viabilitas bakteri (Arizona et al., 2011).

Berdasarkan uji lanjut Tukey menunjukkan bahwa viabilitas Streptococcus sp. (L.10.3) menunjukkan hasil yang berbeda nyata dengan kontrol negatif dan kontrol positif. Hal ini diduga karena pada perlakuan kontrol negatif menggunakan akuades steril yang tidak mengandung senyawa yang dapat menghambat pertumbuhan bakteri. Menurut Moat, (1979) air berperan sebagai pelarut serta alat pengangkut pada proses metabolisme, sehingga air tidak menghambat pertumbuhan bakteri tetapi mendukung pertumbuhan bakteri.

Kontrol positif dalam penelitian ini menggunakan chlorhexidine $0,2 \%$ sebagai zat antibakteri. Chlorhexidine $0,2 \%$ mempunyai persentase penghambatan hingga $99,9 \%$ terhadap Streptococcus sp. (L.10.3). Kandungan bahan dasar chlorine merupakan desinfektan tingkat tinggi karena sangat aktif pada semua bakteri, virus, fungi, parasit, dan beberapa spora (Prijantojo, 1996). Menurut penelitian Mervrayano (2015), obat kumur yang mengandung chlorhexidine $0,2 \%$ lebih efektif dalam menghambat pertumbuhan bakteri golongan Streptococcus dibandingkan dengan povidine iodine yang menunjukkan perbedaan zona hambat sebesar 11,8 mm. Chlorhexidine bekerja dengan cara merusak lapisan luar sel, melintasi dinding sel dan menyerang sitoplasmik bakteri. Hal tersebut mengakibatkan keluarnya kandungan intraseluler sel bakteri dan mengakibatkan kematian pada bakteri (Prijantojo, 1996). 
Jumlah bakteri Streptococcus sp. (L.10.3) setelah diinkubasi dengan asap cair batang manggis $(G$. mangostana L.) paling tinggi terjadi pada konsentrasi $0,1 \%$ sebesar $2,5 \times 10^{7} \mathrm{CFU} / \mathrm{ml}$ dan jumlah bakteri paling kecil terjadi pada konsentrasi $1,5 \%$ sebesar $6,9 \times 10^{5} \mathrm{CFU} / \mathrm{ml}$. Menurut penelitian Luthfi et al., (2015) jumlah bakteri golongan Streptococcus pada gigi yang bebas karies yaitu sebesar $5,1 \times 10^{5} \mathrm{CFU} / \mathrm{ml}$ dan lebih rendah dari jumlah bakteri golongan Streptococcus pada gigi karies sebesar 9,8 x $10^{7} \mathrm{CFU} / \mathrm{ml}$. Berdasarkan hal ini asap cair batang manggis pada konsentrasi 1,5\% efektif dalam mengontrol pertumbuhan Streptococcus sp. (L.10.3) sehingga dapat mencegah terjadinya karies gigi.

Perbedaan jumlah bakteri berbanding terbalik dengan persentase penghambatan, yang ditunjukan semakin tinggi jumlah bakteri (viabilitas bakteri) maka persentase penghambatan semakin rendah. Hal ini karena asap cair batang manggis mengandung senyawa fenol yang menghambat pertumbuhan bakteri, sehingga mempengaruhi tingkat persentase penghambatan. Hasil penelitian menunjukkan penghambatan paling efektif terjadi pada konsentrasi 1,5\%. Konsentrasi 1,5\% dinyatakan efektif karena menunjukkan nilai viabilitas yang rendah dengan nilai penghambatan sebesar 96,9\%. Selain itu berdasarkan hasil uji lanjut Tukey asap cair batang manggis ( $G$. mangostana L.) pada konsentrasi 0,5\% menunukkan hasil yang tidak berbeda nyata dengan chlorhexidine $0,2 \%$.

Perbedaan jumlah Streptococcus sp. (L.10.3) serta persentase penghambatan masing-masing konsentrasi dipengaruhi kandungan senyawa asap cair yang memiliki aktivitas antibakteri. Asap cair mengandung senyawa fenol dan asam seperti asam asetat, propionat, butirat, dan valerat (Fachraniah et al., 2009). Menurut Akbar et al., (2013) asap cair juga mengandung senyawa formaldehid, dimana Menurut Girrard (1992), kombinasi senyawa fenol, formaldehid serta senyawa asam di dalam asap cair mampu membunuh bakteri.

Fenol dapat melarutkan lipid pada dinding sel, sehingga fenol akan berdifusi ke dalam sel dan mengganggu kinerja membran sitoplasma serta menghambat ikatan ATP-ase yang menyebabkan sel menjadi lisis sehingga pertumbuhan bakteri terhambat (Turgis et al., 2009). Soekardjo, (1995) juga menyatakan bahwa fenol dapat merusak sulfohidril dari protein, dan DNA sehingga efektif membunuh bakteri.

\section{DAFTAR PUSTAKA}

Akbar, A, Paindoan, R \& Coniwanti, P, 2013, 'Pengaruh Variabel Waktu dan Temperatur Yanometra couliflora', Jurnal Teknik Kimia, Vol.1, No.18

Arizona, R, Edi, S \& Yuny, E, 2011, 'Pengaruh Konsentrasi Asap Cair Tempurung Kenari Dan Lama Penyimpanan Terhadap Kualitas Kimia Dan Fisik Daging', Jurnal Buletin Peternakan, Vol. 35 No.1, hal. 50-56

Budiarso, F \& Ronald, IO, 2014, 'Isolasi Dan Identifikasi Bakteri Resisten Merkuri Dalam Urine, Feses, Dan Karang Gigi Pada Individu Di Daerah Pesisir Pantai Desa Wineru Kecamatan Likupang Timur Kabupaten Minahasa Utara', Bagian Ilmu Kedokteran Pencegahan Fakultas Kedokteran Unsrat, Vol.1, No.1

Cowan, ST \& Steel's, K., J, 1974, Manual For The Identification Of Medical Bacteria (Second Edition), Cambridge University Press, London

Depertemen Kesehatan RI, 2004, Pedoman Penyelenggaraan Usaha Kesehatan Gigi Dan Sekolah, Jakarta

Depertemen Kesehatan RI, 2012, Rencana Program Pelayanan Kesehatan Gigi dan Mulut, Direktur Jendral Bina Upaya Kesehatan, Jakarta

Fachraniah, Zahra, F \& Zahratur, R, 2009, 'Peningkatan Kualitas Asap Cair Dengan Distilasi', Teknik Kimia Politeknik Negri Lhoksaumawe, Vol.7, No.14

Ginayati, LM, Faisal \& Suhendra, Y, 2015, 'Pemanfaatan Asap Cair Dari Pirolisis Cangkang Kelapa Sawit Sebagai Pengawet Alami Tahu', Teknik Kimia USU, Vol.4, No.3

Girrard, JP, 1992, Tecnology Of Meat and Meat Product, Ellis Horwood, New York

Heriandi, S, \& Yuke, H, 2004, 'Identifikasi Streptococcus mutans dan Streptococcus Sobrinus dengan Morfologi Koloni dan Analisa Biokimia', Jurnal IJD, Vol.11, No.3, hal. 106-10

Holt, JG, Noel R, Krieg, Peter, HA, Sneth, James T \& Staley T, Williams, 1995, Burgey's Manual Of Determinative Bacteriology Edition Ke 9, Lippincott Williams And Wilkins, New York

Judoamidjojo, RM, Said, EG \& Liesbetini, H, 1989, Biokonversi, Pusat Universitas Bioteknologi Institut Pertanian Bogor, Bogor

Luthfi, M, Retno I, Ira, A \& Yoes, PD, 2015, 'Korelasi Jumlah Streptococcus mutans (S. mutans) dan Level Ekspresi Interlukin 8 (IL-8) pada Severe Early Childhood Caries', Artikel Penelitian, Vol.1, No.2, hal. $142-148$ 
Mervrayano, J, Rahmatini \& Elizabeth, B, 2015, 'Perbandingan Efektivitas Obat Kumur yang Mengandung Chlorhexidine dengan Povidone Iodine terhadap Streptococcus mutans', Jurnal Kesehatan Andalas, Vol.4, No.1, hal. 168-171

Moat, AG, 1979, Microbial Physiologi, Jhon Wiley and Sons, New York.

Nahak, MM, 2013, 'Ekstrak Etanol Daun Beluntas (Pluchea indica, L) Dapat Menghabat Pertumbuhan Bakteri Streptococcus mutans', Jurnal Kesehatan Gigi, Vol.1, No.1

Newman, MG, Carranza, FA., Bulkasez, J, Quirynen, M, Teughels, W \& Haake, SK., 2006, Microbiology of Periodontal Disease in Carranza's Clinical Periodontology, Saunders Elseviers, Los Angeles.

Prijantojo, 1996, Antiseptik Sebagai Obat Kumur dan Peranannya Terhadap Pembentukan Plak Gigi dan Radang Gusi, Cermin Dunia Kedokteran, Jakarta

Soekardjo, B \& Siswandono, 1995, Kimia Medisinal,Surabaya, Airlangga University Press, Surabaya

Soelama, H, J, Billy, J, Kepel \& Krista, S, 2015, 'Uji Minimum Inhibitory, Concentration (Mic) Ekstrak Rumput Laut (Eucheuma cottonii) Sebagai Antibakteri Terhadap Streptococcus mutans', Jurnal e-Gigi (eG), Vol.3, No.2

Toelle, N \& Viktor, L, 2014, 'Identifikasi dan Karakteristik Staphylococcus Sp. dan Streptococcus Sp. dari Infeksi Ovarium Pada Ayam Petelur Komersial', Jurnal Ilmu Ternak, Vol.1, No.7, hal. 32-37
Turgis, M, Han J, Caillet S \& Lacroix M, 2009, 'Antimicrobial Activity Of Mustard Essential Oil Against Escherichia coli O157:H7 and Salmonella typhi', jurnal Food Control, Vol.1, No.20, hal. 1073-1079

Wardani, AP, 2012, Pengaruh Pemberian Ekstrak Siwak (Salvadora persica) Pada Berbagai Konsentrasi Terhadap Pertumbuhan Steptococcus mutans, Skripsi, Universitas Diponegoro, Semarang

Waluyo L, 2008, Teknik dan Metode Dasar dalam Mikrobiologi. Universitas Muhammadiyah, Malang

Yefrida, Farrah, A, Indri, TL, Refilda, \& Marniati, S, 2009, 'Uji Aktivitas Anti Bakteri Asap Cair Yang Berasal Dari Batang Kayu Manis Dan Kulit Kacang Tanah', Jurnal Riset Kimia, Vol.2, No.2

Yunita, M, Yusuf, H \& Rini, Y, 2015, 'Analisis Kuantitatif Mikrobiologi Pada Makanan Penerbangan (Aerofood Acs) Garuda Indonesia Berdasarkan Tpc (Total Plate Count) Dengan Metode Pour Plate', Jurnal Keteknikan Pertanian Tropis dan Biosistem, Vol.3, No.3, hal. 237-248 